выражается вопросительно-восклицательной интонацией. Неполное предложение, употреблённое вторым коммуникантом, является средством издевки, адресат намеренно смещает акцент на цвет определённой вещи и уточняет его, чего не ожидает другой участник коммуникации. Причина коммуникативной неудачи, вероятно, неверно выбранная тактика говорящим: прямой вопрос с восклицательной интонацией, что, возможно, вызвало желание адресата уйти от ответа и преднамеренно вывести на негативные эмоции своего собеседника.

-Что там?

-Не здесь же, при всех об этом! Потом! (А. Н. Островский) - в данной коммуникативной ситуации причиной коммуникативной неудачи является неполное предложение «Не здесь же, при всех об этом», потому что коммуникантхочет скрыть истинность событий от инициатора диалога, так как в данном случае им нарушены условия места и времени, что репрезентируют наречие места здесь с отрицательной частицей не и предложно-падежная форма местоимения все и форма предложного падежа об этом указательного местоимения.

Неполное предложение как коммуникативно-функциональная единица русского языка используется в разговорной речи и в ответных репликах героев художественных произведений, с помощью употребления неполных предложений говорящий экономит время передачи информации и сокращает объем этой информации, но сам смысл сообщения при этом не теряется.

Неполные предложения позволяют коммуникантам выразить разнообразные коммуникативные потребности, цели, намерения, реализовать различные реакции на высказывания собеседника.

Неполные предложения реализуют в речи разнообразные свойства и характеризуются полифункциональностью, использование такой функциональнопрагматической единицы может иметь как положительный, так и отрицательный исход.

Анализ примеров показал, что неполные предложения выражают различные коммуникативные намерения говорящего или его собеседника, репрезентируют те или иные иллокутивные цели коммуникантов, среди которых наиболее распространены вопрос, просьба, приказ, угроза, вызывают разнообразные перлокутивные эффекты в форме как вербальной, так и невербальной реакции партнёра по коммуникации.

Неполные предложения как коммуникативно-функциональные единицы русского языка являются причинами коммуникативных неудач, так как использование данного типа синтаксических конструкций в процессе речевой ситуации приводит к созданию условий для недопонимания, появления двусмысленности.

Следовательно, неполное предложение, участвующее в процессе коммуникации, является не только формальным средством общения, но и важным компонентом самого процесса коммуникации, выражая цели, намерения коммуникантов, реализуя функционально-семантические свойства и коммуникативно-прагматические эффекты.

\title{
Sergeeva E.K. Value of English Folk Song
}

$N C F U$ (Russia, Stavropol)

doi:10.18411/spc-22-05-2019-18

idsp: sciencepublic-22-05-2019-18

Song folk art of various ethnic groups is of great value for world culture. It is to give life to people. They contribute to its development, which makes it important for any social sphere of the vital activities of society. 
In this connection, the question arises of cultural and historical value, since folk songs of one nation can significantly expand the circle of folk song senses of other nation. Creating an adequate opinion sets specific tasks for researchers themselves, especially in the case of folk songs, since preserving the cultural realities represented in these works is a top priority. The English folk songs are an integral part of the English songs culture and carry great cultural value due to the spirit of British people described by them.

In folk songs, there is a very unusual language, in which vernaculars, neologisms, dialects and other deviations from the norm of the literary language abound. In this perspective, the analysis of its texts, their cultural characteristics and linguistic stylistic specificity is of value not only for culture, but also for language sciences. In addition, in our opinion, research will benefit in those areas of science and art, where they will be in demand, such as cinema, literature, ethnography or folklore.

The purpose of the study is to identify the historical and cultural features of the English folk songs.

Folk art is one of the main foundations of the ethnos culture. It originates in the very life of the people, the sociocultural existence of the people and the cultural, linguistic concepts that it generates [4, p. 1]. A group of various factors inherent in an ethnos influences the range of meanings of folk art, its specificity and sociocultural orientation since its inception and subsequent development. Thus, the historical past of the ethnos, its ethno cultural origins and origin, geographical location and landscape, climate and those natural rhythms in which the ethnos exists have a significant influence on it [2, p. 1].

Song folk art is of great importance for the language, for its development, its viability. This is a unique sociocultural slice of the people's world perception. Moreover, the lexical, phonetic, morphological, and syntactic units, often unique to the language, presented in the lyrics of folk songs, confirm this point of view [3, p. 2]. From the point of view of the textcentric approach, which implies consideration of the text as a product of creative activity, these texts are the result of many years of observations of the thoughts of the people, their worldview.

Proceeding from all the above, we can assert that a folk song is nothing but a synthesis of folk art, in which the national character, national, cultural traditions, norms and values are preserved for centuries [1, p. 3].

In our opinion, the national-cultural characteristics of the ethnos are most clearly manifested in the language of folklore, in particular, songs that have their own poetics and serve to shape the public consciousness of a certain stratum of society [2, p. 1].

The problem of the connection between language and culture is one of the topical aspects of research in modern science. It is the subject of study not only linguistics, but also related disciplines - sociology, ethnography, cultural studies, folklore. Researchers pay special attention to the functional interaction of the phenomena of "language" and "culture" in the course of the historical development of a particular ethnos. The interrelation of language and culture can be clearly seen in the works of the famous German researcher V. Humboldt, who asserts, "whatever form it takes, there is always a spiritual embodiment of the individual life of the nation."[4, p. 2]

Folk songs often reflected common human values - homesickness, family, and the praises of women's beauty and alcohol. Also in them, the sailors could express their opinions on a particular occasion in a form that would not entail punishment from the authorities. Certain historical events were occasionally celebrated in folk songs, such as the siege of Sevastopol (Sebastopol), the migration of the Irish population to America, and their participation in the US Civil War (Paddy's Lamentation), and the link of criminals from Great Britain to Australia (Jim Jones at Botany Bay) [2, p. 3].

From this point of view, we can say that folk songs were greatly important not only for folk art, but also for history, 'cause they bear historical fact from the peoples point of view. 
Since folk songs are a unique cultural slice that conveys the "people's spirit", mentality, and world perception through verbal expression, we can consider it a unique linguistic phenomenon. The results of folk songs contain unique language units, often unparalleled in other communicative situations [3, p. 2]. However, it should be noted that the language of folk songs is unique in that it is old. Which is of primary interest for both folklorists and linguists.

After analyzing a unique cultural section, folk song art, we concluded that it conveys the spirit of the people, mentality, and perception of the whole ethnos like nothing else. In fact, folk song art is a prism of national consciousness, a unique conductor of the ethnos linguistic culture.

$$
* * *
$$

1. A. Eroshenko. Folk song art as a reflection of national and cultural mentality. 2014.

2. A. Veselovskiy. Historical poetic manner. 1940.

3. M. Vasilyev. Folk music art as an instrument of creative personal fulfillment of personality in extra education. 2008.

4. V. Kulish. Historical memory and mentality: a question about definition. 2016 